\title{
ALIH KODE DAN CAMPUR KODE ANTARA PENJUAL DAN PEMBELI PADA MASA PANDEMI
}

\author{
Tutut Rahayu*1, Nur Khalimah ${ }^{2}$ \\ 1,2, Program Studi Pendidikan Bahasa dan Sastra Indonesia, Fakultas Keguruan dan Ilmu Pendidikan, \\ Universitas Muhadi Setiabudi Brebes, Indonesia. \\ e-mail:*1 tututrahayu1100@gmail.com, ${ }^{2}$ nurkhalimahrahma@gmail.com
}

\begin{abstract}
ABSTRAK
Masyarakat indonesia lebih cenderung menggunakan variasi bahasa pada proses komunikasi dan interaksi sosial. Salah satu variasi bahasa yang sering digunakan yaitu alih kode dan campur kode. Bagi sebagian masyarakat hal yang biasa menggunakan alih kode dan campur kode karena bahasa pertamanya ialah bahasa daerah dan bahasa keduanya yakni bahasa Indonesia. Alih kode dan campur kode adalah pergantian pemakaian bahasa atau ragam bahasa tertentu kedalam bahasa lain. Transaksi jual beli yang terjadi di pasar lebih bervariasi dalam penggunaan variasi bahasa. Oleh karena itu, alih kode dan campur kode antara penjual dan pembeli sangat menarik untuk diteliti. Penelitian ini bertujuan untuk mendeskripsikan wujud alih kode dan campur kode dalam kegiatan jual beli pada masa pandemi. Metode yang digunakan yaitu metode deskriptif kualitatif, yang berlokasi di pasar Kersana. Data dalam penelitian ini berwujud pemakaian bahasa oleh penjual dan pembeli di pasar Kersana pada masa pamdemi pada saat transaksi jual beli. Pengumpulan data penelitian dilakukan dengan menggunakan teknik simak, teknik rekam, dan teknik catatat. Hasil penelitian ini menunjukan bahwa terdapat proses alih kode dan campur kode dalam pemakaian antara penjual dan pembeli di pasar Kersana. Dengan demikian, penggunaan alih kode dan campur kode antara penjual dan pembeli dipengaruhi adanya kebiasaan penutur, mitra tutur, kehadiran penutur ketiga, dan situasi pembicaraan tertentu serta kemampuan pemakaian bahasa yang dilatar belakangi oleh tingkat pendidikan baik penjual dan pembeli.
\end{abstract}

Kata kunci : Alih kode, Campur kode, Masa pandemi

\begin{abstract}
Indonesian people are more likely to use language variations in the process of communication and social interaction. One variation of language that is often used is code switching and code mixing. For some people it is usual to use code switching and code mixing because the first language is the local language and the second language is Indonesian. Code switching and code mixing are changes in the use of certain languages or languages into other languages. Buying and selling transactions that occur in the market are more varied in the use of language variations. Therefore, code switching and code mixing between seller and buyer are very interesting to study. This study aims to describe the form of code switching and code mixing in the buying and selling activities during the pandemic. The method used is descriptive qualitative method, which is located in the Kersana market. The data in this study take the form of the use of language by sellers and buyers in the Kersana market during the Pamdemic during the sale and purchase transaction. Research data collection was carried out by using listening techniques, record techniques, and note taking techniques. The results of this study indicate that there is a process of code switching and code mixing in usage between sellers and buyers in the Kersana market. Thus, the use of code switching and code mixing between the seller and the buyer is influenced by the habits of the speaker, the speech partner, the presence of the third speaker, and the specific situation of conversation as well as the ability to use language which is motivated by the level of education of both the seller and the buyer.
\end{abstract}

Keywords: Code switching, Mix codes, pandemic period 


\section{PENDAHULUAN}

Bahasa merupakan suatu alat komunikasi dan interaksi terpenting bagi manusia untuk berhubungan dengan manusia lainnya. Bahasa juga dijadikan alat yang paling sentral bagi kelancaran komunikasi tersebut, karena bahasa dapat menyampaikan segala bentuk pemikiran manusia.

Setiap penutur mempunyai kemampuan komunikatif berupa kemampuan berbahasa serta kemampuan mengungkapkan bahasa sesuai dengan fungsi dan norma-norma pemakaian dalam konteks sosialnya [1]. Pengunaan bahasa pada setiap penutur bahasa mempunyai perbedaan bergantung pada bahasa yang digunakan dan cara menggunakan bahasa itu oleh masing-masing pengguna bahasa.

Dalam berkomunikasi, terkadang orang tidak hanya menggunakan satu bahasa saja. Sebuah fenomena menarik yang saat ini sering terjadi yaitu banyaknya orang melakukan pergantian (alternation) kode, baik alih kode (code switching) maupun campur kode (code mixing) dalam berkomunikasi dengan orang lain. Dalam kamus linguistik, alih kode adalah penggunaan variasi bahasa lain atau bahasa lain untuk menyesuaikan diri dengan peran atau situasi lain atau karena adanya partisipan lain, sedangkan campur kode adalah penggunaan satuan bahasa dari satu bahasa ke bahasa lain untuk memperluas gaya bahasa atau ragam bahasa, termasuk didalamnya pemakaian kata, klausa, idiom, dan sapaan.[2] Dalam interaksi jual beli yang terdapat di pasar banyak ditemukan campur kode dan alih kode. Adanya campur kode dan alih kode selama tuturan berlangsung merupakan hal wajar yang di pakai penjual dan pembeli saat bertransaksi. Sebagai masyarakat dwibahasawan, masyarakat di pasar tentunya juga memiliki bahasa yang dipakai dalam berkomunikasi antara penjual dan pembeli[3]. Seperti penjual dan pembeli di pasar Kersana, dalam pemakaian bahasa para pedagangan di pasar Kersana mayoritas dari mereka menguasai bahasa jawa walaupun ada beberapa yang menggunakan bahasa sunda. Karena bahasa tersebut merupakan bahasa yang pertama kali dikuasai. Bahasa Indonesia yang dipakai oleh penjual untuk berkomunikasi merupakan bentuk-bentuk tuturan untuk menghormati pembeli, karena dilihat dari setatus sosial atau dari segi penampilan.

Pasar merupakan satu pusat interaksi masyarakat yang cenderung memiliki budaya dan norma tertentu yang dijadikan pola dan kesepakatan aturan dalam interaksi sosialnya. Pasar Kersana merupakan pasar besar yang berada di Desa Cigedog Kecamatan Kersana Kabupaten Brebes. Lebih dari 100 pedagang yang berjualan didalam pasar tersebut, dan setiap harinya ramai oleh pembeli. Pasar Kersana merupakan pasar yang berlokasi sangat strategis yaitu tepat berada di dekat perempatan lampu merah Kersana. Di pasar Kersana para penjual dan pembeli mayoritas menggunakan bahasa jawa ngoko (bahasa disekitar desa tersebut) tetapi ada beberapa orang juga menggunakan bahasa Indonesia. Negara Indonesia sekarang ini sedang mengalami bencana yaitu wabah virus corona (covid19), yang bermula dari Negara Cina yang bertepat di Wuhan. Banyak warga di Indonesia terkena virus corona ini, virus ini banyak memakan korban bahkan hingga puluhan ribu warga. Namun demikian, berbeda dengan kondisi pasar di Kersana, meski sedang dalam masa pandemi seperti ini pasar Kersana masih beroprasi seperti biasa setiap harinya dengan mematuhi beberapa prosedur yang dianjurkan oleh pemerintah; seperti cuci tangan dan menggunakan masker jika memasuki area pasar tersebut.

Dalam penelitian ini, peneliti memilih pasar Kersana menjadi objek penelitian. Dipilihnya lokasi tersebut karena transaksi jual beli di pasar Kersana menggunakan variasi bahasa, dan memiliki latar belakang yang berbeda.

Dari latar belakang yang sudah penulis kemukakan diatas maka penulis merumuskan masalah dalam penelitian ini yaitu "Bagaimana wujud alih kode dan campur kode antara penjual dan pembeli pada masa pandemi di pasar Kersana?"

Tujuan dari penelitian ini adalah untuk mengetahui bagaimana alih kode dan campur kode antara penjual dan pembeli pada masa pandemi di pasar Kersana. 
Jurnal SEMANTIKA, Volume 2, No. 01, Agustus 2020, pp. 52-61

Alih kode merupakan pergantian (perpindahan dari satu varian bahasa kedalam bentuk satuan bahasa lainnya [4]. Alih kode dalam pemahaman sebagai gejala adanya kebergantungan fungsi kontekstual dan situasi renasional pada gejala pemakaian dua bahasa atau lebih. Oleh karena itu, alih kode lebih ditekankan pada gejala pemakaian bahasa karena perubahan situasi [5]. Selain alih kode yang terjadi dari satu bahasa ke bahasa yang lain atau antar bahasa. Telah disebutkan di atas, juga terjadi alih kode dari dialek ke dialek yang lain dalam satu bahasa. [6]

Menurut [7] alih kode adalah penggunaan variasi bahasa lain atau bahasa lain dalam satu peristiwa bahasa sebagai strategi untuk menyesuaikan diri dengan peran atau situasi lain, atau karena adanya partisipan lain.

Alih

kode adalah istilah umum untuk menyebutkan pergantian atau peralihan pemakaian dua bahasa atau lebih, beberapa variasi dari satu bahasa, atau bahkan beberapa gaya dari suatu ragam. Dia juga menyebut apa yang disebut alih kode intern (internal code switching), yakni yang terjadi antarbahasa daerah dalam suatu bahasa nasional, antardialek dalam satu bahasa daerah, atau antara beberapa ragam dan gaya yang terdapat dalam suatu dialek. Adapun yang dimaksud dengan alih kode ekstern (external code switching) adalah peralihan bahasa yang terjadi antara bahasa dasar (base language) dengan bahasa asing. [2]

Adapun penyebab alih kode, yaitu "siapa berbicara, dengan bahasa apa, kepada siapa, kapan, dan dengan tujuan apa". Secara umum, penyebab alih kode adalah (1) pembicara atau penutur, (2) pendengar atau lawan tutur, (3) perubahan situasi dengan hadirnya orang ketiga, (4) perubahan dar formal ke informal, (5) perubahan topik pembicaraan. [8]

Berdasarkan uraian diatas dapat di simpulkan bahwa alih kode adalah pemakaian atau pergantian dua bahasa atau lebih dalam perubahan situasi atau dalam konteks tertentu.

Peristiwa campur kode terjadi apabila seorang penutur bahasa, misalnya bahasa Indonesia memasukkan unsur-unsur bahasa daerah ataupun bahkan memasukkan unsur-unsur bahasa asing kedalam pembicaraan bahasa Indonesianya tersebut. Dengan katalain, seseorang yang berbicara dengan kode utama bahasa Indonesia yang mempunyai fungsi keotonomiannya, sedangkan kode bahasa daerah atau bahasa asing yang terlibat dalam kode utama tersebut merupakan serpihanserpihan saja tanpa fungsi atau keotonomian sebagai sebuah kode. [9]

Campur kode yaitu penggunaan satuan bahasa dari satu bahasa kedalam bahasa lain untuk memperluas gaya bahasa atau ragam bahasa; termasuk didalamnya pemakaian kata, klausa, idiom,dan sapaan. Terkait dengan batasan campur kode, bahwa "conversational code-mixingin involves the deliberate mixing of two language without an associated topic change". Tuturan campur kode secara sengaja melibatkan campuran dari dua bahasa tanpa merubah keutuhan topik pembicara. [10]

Suatu peristiwa tutur apabila di dalamnya terdapat klausa-klausa atau frase-frase yang digunakan terdiri dari klausa dan frase campuran (hybrid clauses, hybrid phrases), dan masingmasing klausa dan frase tidak lagi mendukung fungsi sendiri-sendiri, maka peristiwa yang terjadi ini adalah campur kode.[11]

Menurut [12] alih kode ialah "where domain is not well defined... speakers can be heard code-mixing" (dimana ranah tidak terlalu jelas... kita mendengar orang melakukan campur kode). Terjadinya campur kode bahasa yang satu dengan bahasa yang lain juga sering disebabkan karena adanya penyisipan klausa dari bahasa daerah (terutama bahasa Jawa dan bahasa Sunda) terhadap bahasa Indonesia dalam percakapan sehari-hari baik ketika sedang berdiskusi, bertransaksi, atau jenis komunikasi yang lainnya. [13]

Campur kode terjadi apabila didalam suatu peristiwa tutur, klausa-klausa maupun frasefrase yang digunakan terdiri dari klausa dan frase campuran (hybrid clause, hybrid phrases) ", dan masing-masing klausa atau frase itu tidak lagi mendukung fungsi sendiri-sendiri adalah campur kode bukan alih kode. Campur kode itu dapat berupa percampuran serpihan kata, frase, dan klausa suatu bahasa di dalam bahasa lain yang di gunakan." Intinya, ada satu bahasa yang di gunakan, tetapi di dalamnya terdapat serpihan-serpihan dari bahasa lain. [14]

Jenis campur kode berdasarkan asal usul serapannya dibedakan menjadi tiga jenis yaitu campur kode kedalam (inner code mixing) adalah camupr kode yang menyerap unsur-unsur bahasa asli yang masih sekerabat, campur kode ke luar (outer code mixing) adalah campur kode 
yang menyerap unsur-unsur bahasa asing, campur kode campuran (hybrid code mixing) adalah campur kode yang di dalamnya (mungkin klausa atau kalimat) telah menyerap unsur bahasa asli (bahasabahasa daerah) dan bahasa asing. [11]

Dari uraian di atas maka dapat di ambil simpulan yaitu bahwa campur kode adalah penggunaan dua bahasa atau lebih yang dengan memasukkan unsur-unsur bahasa yang satu kedalam bahasa yang lain.

Pasar kersana merupakan salah satu pasar utama yang ada di Kecamatan Kersana. Pasar Kersana berlokasi di Jl. Raya Kersana No. 26, RT 01 Desa Cigedog Lor (Plasmen), Kecamatan Kersana, Kabupaten Brebes, Provinsi Jawa Tengah, lebih tepatnya di samping perempatan lampu merah Kersana berdekatan dengan PG Tersana Baru unit Ketanggungan Barat peninggalan Belanda.

Luas dari pasar Kersana sendiri kurang lebihnya $1 \mathrm{Ha}$, dengan jumlah pedagang 200-250. Pasar Kersana merupakan salah satu area yang digunakan warga setempat bahkan diluar desa tersebut untuk melakukan transaksi jual beli.

Pasar Kersana juga merupakan pasar yang paling lengkap yang ada di Kecamatan Kersana dengan harga terjangkau. Pasar Kersana biasanya mulai beroprasi setiap harinya dari jam 05.00 sampai jam 17.00 WIB.

\section{METODOLOGI PENELITIAN}

Metode yang digunakan dalam penelitian ini yaitu deskriptif kualitatif. Penelitian deskriptif adalah metode yang bertujuan membuat deskripsi, maksudnya membuat gambaran, lukisan secara sistematis, faktual, dan akurat mengenai data, sifat-sifat serta hubungan fenomenafenomena yang diteliti. Penelitian kualitatif cenderung tidak memotong halaman cerita dan data lainya dengan simbol-simbol angka. Dalam penelitian kualitatif peneliti harus dapat memaparkan data secara terperinci dan tidak boleh menghilangkan bagian yang ada kaitanya dengan penelitian. Selain itu dengan menggunakan metode ini fenomena kebahasaan yang hendak diteliti oleh peneliti akan mendapatkan hasil yang lebih akurat. [3]

Lokasi penelitian ini di pasar Kersana Desa Cigedog Kecamatan Kersana Kabupaten Brebes. Lokasi ini dipilih karena di pasar Kersana salah satu terjadinya transaksi terbesar yang ada di Kecamatan Kersana, dan juga pasar Kersana mayoritas penjual dan pembelinya menggunakan variasi bahasa yaitu alih kode dan campur kode.

Sumber data dari penelitian ini adalah penjual dan pembeli yang berada di pasar Kersana. Sasaran yang menjadi sumber informasi antara lain; penjual ayam, penjual sayur mayur, penjual jajanan pasar, penjual sembako, penjual ikan, dan penjual tempe serta pembeli yang berasal dari masyarakat sekitar yang ada di pasar Kersana Desa Cigedog Kabupaten Brebes Provinsi Jawa Tengah.

Instrumen penelitian ini adalah peneliti sebagai instrumen kunci dan menggunakan alat bantu yang berupa panduan observasi dan merekam peristiwa alih kode dan campur kode bahasa daerah dengan bahasa Indonesia, yang digunakan masyarakat dalam penggunaan bahasa di pasar Kersana Desa Cigedog Kecamatan Kersana Kabupaten Brebes Provinsi Jawa Tengah.

Teknik pengumpulan data yang digunakan pada panelitian ini yaitu observasi, teknik catat, dan teknik rekam. Menurut sifat observasi, terdiri dari observasi stematis yaitu observasi yang dilakukan menurut struktur yang berisikan faktor-faktor yang telah diatur berdasarkan kategori, masalah yang hendak diobservasi; dan observasi non sistematis yaitu observasi yang dilakukan tanpa struktur atau rencana terlebih dahulu, dengan demikian observer dapat menangkap apa saja yang dapat ditangkap. [15]

Teknik catat digunakan peneliti untuk mencatat konteks atau situasi tutur atau pemakaian bahasa yang digunakan oleh penjual dan pembeli di pasar Kersana yang sesuai dengan unsurunsur alih kode dan campur kode. Kemudian teknik lanjutannya adalah teknik rekam yaitu merekam pemakaian bahasa lisan yang bersifat spontan, kegiatan merekam ini cenderung dilakukan tanpa sepengetahuan penutur sumber data atau pembicara, selanjutnya teknik catat 
Jurnal SEMANTIKA, Volume 2, No. 01, Agustus 2020, pp. 52-61

yaitu memperoleh data dengan mencatat data kebahasaan atau istilah-istilah yang relevan sesuai dengan sasaran dan tujuan penelitian. Teknik catat dalam penelitian ini adalah mencatat penggunaan bahasa atau mentranskrisi penggunaan bahasa lisan menjadi data tulis yang sesuai dengan kenyataan. [10]

Teknik analisis data dalam penelitian adalah data-data yang telah dikumpulkan selanjutnya diseleksi. Data-data yang sudah terseleksi kemudian dikelompokan. Setelah dikelompokan lalu di analisis dengan menggunakan analisis Sosiolinguistik (Konteks, penutur, tuturan, tujuan, situasi, dan tempat). Adapun tahap-tahap yang di tempuh dalam menganalisis data adalah sebagai berikut :

1. Transkripsi data, yaitu memindahkan dari data lisan ke data tertulis ke dalam bahasa Indonesia.

2. Terjemahan, yaitu pengalihan dari bahasa sumber (Jawa) ke bahasa sasaran yaitu bahasa Indonesia.

3. Klasifikasi data, yaitu semua data dikumpulkan sesuai dengan karakteristik maknanya.

4. Analisis data, pada tahap ini peneliti berusaha untuk menganalisis semua data yang terkumpul berdasarkan makna pada setiap tuturan.

5. Deskripsi data, pada tahap ini peneliti berusaha memaparkan data temuan yang di temukan dilapangan. [5]

\section{HASIL DAN PEMBAHASAN}

\section{Hasil Penelitian}

\section{Wujud Alih Kode antara Penjual dan Pembeli di Pasar Kersana}

Analisis data yang berhasil dikumpulkan pada wujud alih kode dimana menggunakan dua bahasa, yakni; bahasa daerah (Jawa) dan bahasa Indonesia. Bahasa Jawa lebih dominan digunakan karena bahasa Jawa merupakan bahasa yang digunakan dalam percakapan oleh para penjual dan pembeli yang ada di pasar Kersana sekaligus menjadi bahasa dasar yang akan menjadi fokus dari peristiwa alih kode. Dengan demikian, alih kode ini berfokus pada peralihan dari bahasa Jawa dan bahasa Indonesia.

Wujud alih kode yang dianalisis adalah alih kode yang dominan yang digunakan antara penjual dan pembeli di pasar Kersana dalam kegiatan transaksi jual beli. Berikut data alih kode yang ditemukan di pasar Kersana:

Pembeli : : mbak tuku iwake sekilo mene.

Penjual : iwak sing ndi bu?

Pembeli : : kue sing iwak jaer pira mbak

Penjual : yang ini tigalima bu

Pembeli : ikan lele berapa

Penjual : ari iwak lele rongpuluh

Pembeli : ganing larang nemen mbak, yong biasane gen kur limalas tok

Penjual : iya bu, yong barange lagi angel goleti kulakane gen ora olih semono

Pembeli : : wis dadine jaer kro lelene seket, jaere telulima lelene limalas

Penjual : : tambahi tiga ribu lagi bu

Pembeli $\quad$ : iya sudah ikan lele satu kilo ikan mujaernya satu kilo ya bu.

Alih kode yang terjadi pada penjual ikan di pasar Kersana adalah peralihan dari bahasa Jawa kedalam penggunaan bahasa Indonesia dalam melakukan tawar menawar pada transaksi jual beli. Pada percakapan diatas pembeli menyakan harga beberapa harga ikan kepada penjual ikan.

Selanjutnya wujud alih kode ditemukan pada kios pakaian namun dalam hal ini lebih dari dua pembeli yang berada di pasar Kersana. Berikut data alih kode yang ditemukan di pasar Kersana dalam melakukan transaksi. 
Penjual : monggo kie kelambine metuan anyar kabeh, monggo ibu dideleng deleng.

Pembeli 1 : goleti duwuran mbak sing metuan anyar kaya apa.

Pembeli 2 : sisan karo rok sing ireng kue mbak

Penjual : : ini baju dan androknya bu keluara terbaru semua.

Pembeli 1 : kaya kie apik belih jare kowen

Pembeli 2 : apik yu

Pembeli 1 : : ini ada warna lain mba (sambil menujukan baju)

Penjual : ada bu nanti saya ambilkan

Pembeli 2 : yu, kue androke ora sedeng

Penjual : nanti saya ambilkan soalnya banyak ukuranya bu

Pembeli 1 : ya wis mba sing rada gede secuil maning

Alih kode yang terjadi di kios pakaian ini adalah peralihan bahasa Jawa ke dalam penggunaan bahasa Indonesia dalam proses transaksi jual beli, dimana awalnya penjual menawarkan barang dan ada pembeli yang menanyakan model dan warna dari pakaian tersebut.

Selanjutnya wujud alih kode terjadi di kios buah yang berada di pasar Kersana, dimana pembeli dan penjual menggunkan bahasa Jawa Krama (bahasa Jawa yang halus) diperalihkan kedalam bahasa Indonesia. Berikut data alih kode yang ditemukan.
Pembeli : gedang niki regine pinten mba.
Penjual : satu ikat duapuluh ribu bu.
Pembeli : awis sanget bu, wingi amung kalihwelas saniki sampun kalihdoso mawon. (sambil memilah-milah buah pisang)
Penjual : nggih bu, yong pripun nggih, yong saniki saweg wonten pandemi kados niki dadose awis sedoyo bu, saking mrikone gen sampun awis bu, dadose dugi mriki nggih rada awis bu, kulo gen keder badhe sadeane regi pinten, diawisi nggih melas kayong kabehane sarwa angel bu
Pembeli $\quad$ : iya bu, kaya gini jadi susah semua yah bu.
Penjual : iya bu, semua ikut mahal yang kaya gini di desa pun kena imbasnya.
Pembeli : niki mboten saged kurang bu, badhe kulo tumbas sedoyo.
Penjual : ya dikurangi duaribu ajah bu
Pembeli : nggih pun niki kulo tumbas sedoyo

Bentuk alih kode yang digunakan antara penjual dan pembeli di kios buah adalah peralihan dari bahasa Jawa Krama (bahasa Jawa halus) kedalam bahasa Indonesia. Pada pembicaraan antara penjual dan pembeli tersebut penjual menginformasikan kenaikan harga pisang pada saat ada pendemi seperti ini.

\section{Wujud Campur Kode antara Penjual dan Pembeli di Pasar Kersana}

Wujud campur kode yang ditemukan di pasar Kersana adalah melibatkan bahasa Jawa dan bahasa Indonesia. dalam bentuk penyisipan unsur-unsur bahasa Indonesia kedalam unsurunsur bahasa Jawa.

Di pasar Kersana kecenderungan pemakaian dua bahasa terjadi dalam kondisi lisan pada saat penjual dan pembeli melakukan transaksi jual beli. Di dalam campur kode, ciri-ciri ketergantungan itu ditandai oleh hubungan timbal balik antara peranan (siapa yang menggunakan bahas itu) dan fungsi kebahasaan (apa yang ingin dicapai oleh penutur dengan tuturannya itu). Dalam peristiwa campur kode, unsur-unsur bahasa atau variasi-variasi yang menyisip di dalam bahasa lain tidak lagi mempunyai fungsi tersendiri. Unsur-unsur itu telah menyatu dengan bahasa yang disisipinya, dan secara keseluruhan hanya mendukung satu fungsi. Dalam kondisi maksimal, campur kode merupakan konvergensi kebahasaan yang unsur-unsurnya berasal 
dari beberapa bahasa, masing-masing telah menanggalkan fungsinya dan mendukung fungsi bahasa yang disisipinya. [2]

Unsur terbesar dalam campur kode yaitu pembatasan pada klausa. Artinya, misalkan unsur bahasa menyisipkan dalam campur kode itu adalah satuan diatas klausa (misalnya; kalimat, rangkaian kalimat bahkan paragraph) maka tidak dapat diidentifiasi sebagai campur kode melainkan alih kode.

Wujud campur kode terjadi di toko sembako yang ada di pasar Kersana, saat transaksi jual beli. Wujud campur kode yang terjadi adanya penyisipan bahasa Indonesia ke dalam bahasa Jawa. Berikut data campur kode yang ada di toko sembako;

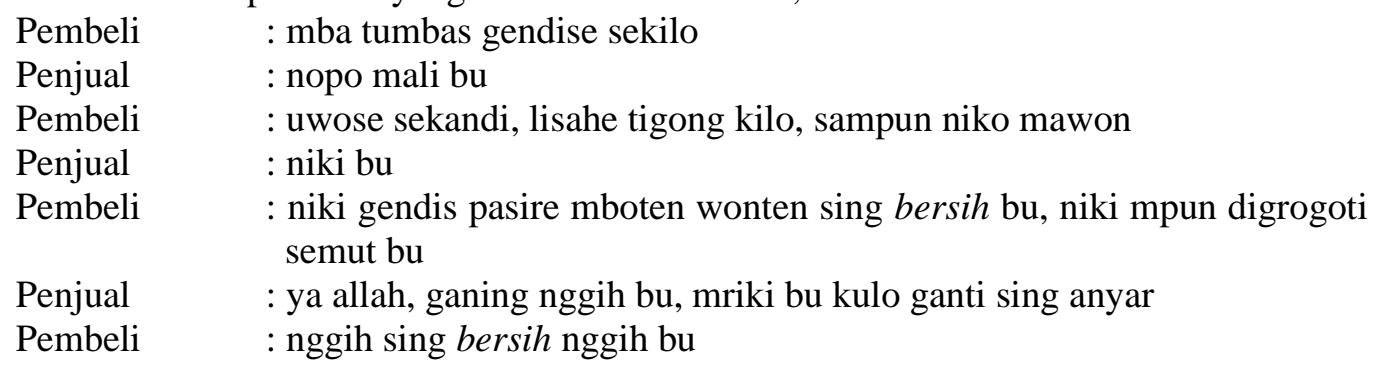

Kegiatan tersebut berlangsung di toko sembako yang ada di pasar Kersana. Adapun wujud campur kode yang ada di dalam percakapan adalah penggunaan frasa yaitu kata "bersih". Pada awalnya pembeli menggunakan bahasa Jawa namun ada penyisipan bahasa Indonesia yang digunakan dalam tuturan antara penjual dan pembeli dan itu termasuk kedalam campur kode.

Selanjutnya wujud campur kode yang dilakukan antara penjual dan pembeli di toko perabotan yang ada di pasar Kersana. Wujud campur kode yang digunakan ada beberapa penyisipan bahasa Indonesia kedalam bahasa Jawa. Berikut data campur kode yang ditemukan.

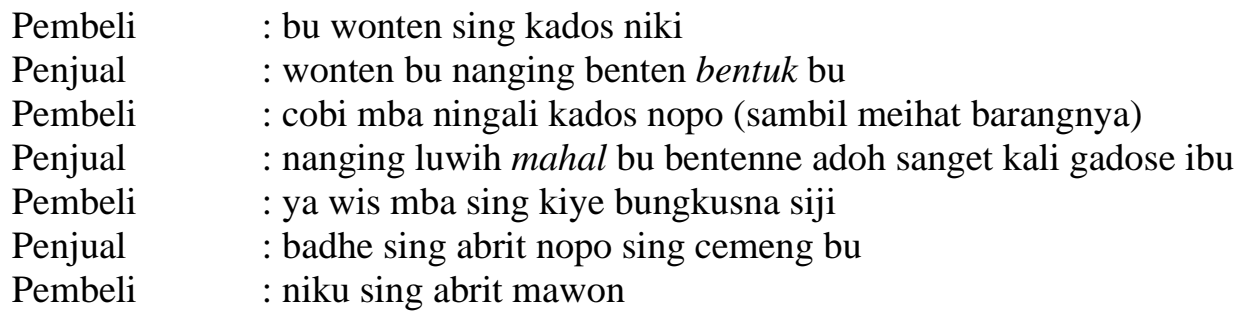

Wujud campur kode yang digunakan penjual dan pembeli dalam percakapan tersebut yaitu menyisipkan bahasa Indonesia kedalam bahasa Jawa, menggunakan frasa yaitu kata "bentuk" dan "mahal". Pada tuturan antara penjual dan pembeli diawali dengan pembeli yang menanyakan barang yang sama seperti yang dibawanya dengan menggunakan bahasa Jawa namun pada akhirnya percakapannya mengandung unsur dari campur kode frasa dalam bahasa Indonesia.

\section{Pembahasan}

Pembeli : gedang niki regine pinten mba.

Penjual : satu ikat duapuluh ribu bu.

Pembeli : awis sanget bu, wingi amung kalihwelas saniki sampun kalihdoso mawon. (sambil memilah-milah buah pisang)

Penjual : nggih bu, yong pripun nggih, yong saniki saweg wonten pandemi kados niki dadose awis sedoyo bu, saking mrikone gen sampun awis bu, dadose dugi mriki nggih rada awis bu, kulo gen keder badhe sadeane regi pinten, diawisi nggih melas kayong kabehane sarwa angel bu

Pembeli : : iya bu, kaya gini jadi susah semua yah bu. 


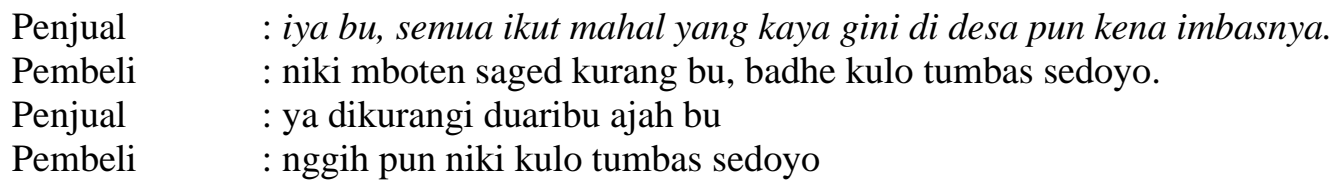

Pada kalimat "satu ikat duapuluhribu" dituturkan penjual buah dengan menggunakan unsur alih kode. Kalimat tersebut di tuturkan oleh penjual menggunakan bahasa Jawa yang kemudian di alihkan menjadi bahasa Indonesia. Namun pada kalimat "awis sanget bu, wingi amung kalihwelas" (mahal banget mba, kemaren cuma duabelas) terjadi penolakan harga yang tidak disetujui oleh pembeli. Penjual beralasan "saniki saweg wonten pandemi" (sekarang sedang ada pandemi) sehingga memberikan keyakinan pada pembeli mengenai harga pisang yang akan dijual kepada pembeli. Pembeli menerima alasan yang di berikan oleh penjual "nggih pun niki kulo tumbas sedoyo" (ya sudah ini saya beli semuanya).

Berdasarkan tuturan yang dilakukan penjual dan pembeli memiliki prinsip-prinsip alih kode. Prinsip tutur dar percakapan antara penjual dan pembeli yaitu prinsip kerja sama dan kesopanan. Dengan prinsip kerja sama menjadikan penjual dan pembeli saling memahami masud dari tuturan yang di ucapkan, sehingga dapat dengan mudah berkomunikasi mengenai harga buah pisang berjalan dengan lancar, serta prinsip kesopanan dimana penjual dan pembeli berinteraksi dengan baik, pembeli membeli buah pisang dengan harga yang telah disepakati oleh kedua belah pihak yaitu penjual dan pembeli.

Dalam transaksi jual beli antara penjual dan pembeli mayoritas orang menggunakan variasi bahasa. Salah satunya yaitu alih kode dan campur kode. Alih kode dan campur kode di pasar Kersana menggunakan bahasa Jawa Brebes khususnya saat kegiatan transaksi jual beli. Alih kode dan campur kode sering digunakan dalam bertutur di pasar Kersana dikarenakan mayoritas orang yang sudah terbiasa menggunakan dwibahasa atau variasi bahasa, sehingga alih kode dan campur kode merupakan variasi bahasa yang sering digunakan.

Dalam bertutur, sudah barang tentu seorang penutur dan mitra tutur memiliki topik pembicaraan yang merupakan inti dari tuturan yang dimaksud. Topik pembicaraan tersebut terkadang serius namun tidak menutup kemungkinan untuk membangkitkan rasa humor ataupun untuk sekadar gengsi apalagi dengan alih kode dan campur kode yang terjadi.

Berdasarkan temuan yang diperoleh bahwa penjual dan pembeli menggunakan dua bahasa ketika bertransaksi bertujuan untuk meningkatkan kepahaman antara penjual dan pembeli itu sendiri. Hal ini dikarenakan banyak pembeli yang berasal dari luar daerah yang dikhawatirkan kurang memahami percakapan menggunakan bahasa Jawa. Selain, penjual hanya ingin mengimbangi apabila pembeli menggunakan bahasa Indonesia maka ia pun menggunakannya dan begitu sebaliknya. Pada intinya variasi yang digunakan yaitu untuk menjalin keakraban dengan pembeli serta menghindari kesalahpahaman ketika bertransaksi. [2]

\section{SIMPULAN}

Berdasarkan hasil peneliti alih kode dan campur kode antara penjual dan pembeli pada masa pandemi yang berlokasi di pasar Kersana, diperoleh hasil sebagai berikut. Petama, proses transaksi jual beli dan komunikasi di pasar Kersana terjadi dua penggunaan yaitu alih kode dan campur kode. Alih kode yang terjadi di pasar Kersana yaitu pergantian penggunaan bahasa Jawa dan bahasa Indonesia, sedangkan campur kode yang terjadi di pasar Kersana penyisipan frasa berbentuk bahasa Indonesia kedalam Bahasa Jawa. Kedua, alih kode dan campur kode banyak dipakai masyrakat pada saatberkomunikasi dan interaksi dalam transaksi jual beli di pasar Kersana seperti di penjual ikan, penjual buah, toko sembako, toko pakaian, dan toko perabotan. Ketiga, penyebab alih kode dan campur kode dalam interaksi jual beli di pasar Kersana adalah kesamaan bahasa antara penjual dan pembeli, sehingga mudah untuk saling memahami maksud dari tuturan yang sedang di ujarkan, sudah kenal atau akrab antara penjual dan pembeli tersebut jadi lebih mudah menggunakan alih kode dan campur kode, dan fungsi dari alih kode dan campu 
Jurnal SEMANTIKA, Volume 2, No. 01, Agustus 2020, pp. 52-61

kode dalam ranah perdagangan di pasar Kersana yaitu untuk saling menghormati jika ada penjual atau pembeli yang tidak bisa dengan lancar menggunakan bahasa setempat yaitu bahasa Jawa.

\section{REFERENCES}

[1] L. Akhii, N. Rahayu and C. Wulandari, "Campur kode dan alih kode dalam percakapan di lingkup perpustakaan universitas bengkulu," Jurnal Ilmiah Korpus, vol. 2, no. 1, pp. 45-48, 2018, [Online]. Available: https://ejournal.unib.ac.id/index.php/korpus/article/view/5556

[2] D. A. Mustikawati, "Alih kode dan campur kode antara penjual dan pembeli (analisis pembelajaran berbahasa melalui studi sosiolinguistik)," Jurnal Dimensi Pendidikan dan Pembelajaran, vol. 3, no. 2, pp. 23-26, 2015, [Online]. Available: http://journal.umpo.ac.id/index.php/dimensi/article/view/154/141

[3] Wijaya, G, A., Campur kode dan alih kode tuturan dalam perdagangan di pasar klewer surakarta, Publikasi Ilmiah, Fakultas Keguruan dan Ilmu Pendidikan, Universitas Muhamadiah Surakarta, 2016, Surakarta.

[4] A. Fauziyah, Itaristanti, and I. Mulyaningsih, "Fenomena Alih Kode Dan Campur Kode Dalam Angkutan Umum (Elf) Jurusan Sindang Terminal_Harjamukti Cirebon," Jurnal Pendidikan Bahasa dan Sastra Indonesia, vol. 2, no. 2, pp. 79-83, 2019, [Online]. Available: http://e-journal.hamzanwadi.ac.id/index.php/sbs/article/view/1334/943

[5] W. O. Marni, "Campur kode dan alih kode dalam peristiwa jual beli di pasar labuan tobelo kecamatan wakorumba utara kabupaten buton utara,"8 Jurnal Bastra (Bahasa Dan Sastra), vol. 2, no. 1, pp. 1-7, 2016, [Online]. Available: http://ojs.uho.ac.id/index.php/BASTRA/article/view/1529/1082

[6] Herman, "Alih kode bahasa dalam interaksi jual beli di pasar inpres manonda kota palu," Jurnal Bahasa dan Sastra Untad, vol. 2, no. 2, pp. 1-3, 2013 [Online]. Available: http://jurnal.untad.ac.id/jurnal/index.php/BDS/article/view/2179/1391

[7] Susilo, E., Alih kode dalam interaksi pedagang dan pembeli di kawasan kaki lima malioboro yogyakarta, Skripsi, Fakultas Bahasa dan Seni, Universitas Negeri Yogyakarta, 2016, Yogyakarta.

[8] Rokhman, F., Sosiolingiustik Suatu Pendekatan Pembelajaran dalam Masyarakat Multikultural, Ed. 1, 2013, Graha Ilmu, Yogyakarta.

[9] Nugroho, A., Alih kode dan campur kode pada komunikasi guru-siswa di sma negeri 1 wonosari klaten, Skripsi, Fakultas Bahasa dan Seni, Universitas Negeri Yogyakarta, 2011, Yogyakarta.

[10] Vinansis, M. R., Alih kode dan campur kode bahasa jawa dalam rapat ibu-ibu pkk di kepatihan kulon surakarta (suatu kajian sosiolinguistik), Skripsi, Fakultas Sastra dan Seni Rupa, Universitas Sebelas Maret, 2011, Surakarta.

[11] Annisa, I. N. Suandi, and M. S. Indriani, "Campur kode dalam transaksi jual beli pada media online shop di singaraja dan denpasar," e-Journal Program Studi Pendidikan Bahasa dan Sastra Indonesia, vol. 4, no. 2, pp. 1-3, 2016 [Online]. Available: https://ejournal.undiksha.ac.id/index.php/JJPBS/article/view/8536/5576

[12] Suhardi, B., Pedoman Penilitian Sosiolinguistik, 2009, Pusat Bahasa Departemen Pendidikan Nasional, Jakarta.

[13] A. Srihartatik, and S. Mulyani, "Alih kode dan campur kode masyarakat tutur di pasar tradisional plered cirebon", Jurnal Literasi (Jurnal Penelitian Bahasa Dan Sastra Indonesia Serta Pembelajaranya), vol. 1, no. 2, pp. 33-36, 2017, [Online]. Available: https://jurnal.unigal.ac.id/index.php/literasi/article/view/784/689

[14] N. Mersita, "Alih kode dan campur kode dalam tuturan penjual dan pembeli sayur di pasar baru majenang kabupaten cilacap," Jurnal Literasi (Jurnal Penelitian Bahasa Dan Sastra Indonesia Serta Pembelajaranya), vol. 2, no. 2, pp. 88-90, 2018, [Online]. Available: https://jurnal.unigal.ac.id/index.php/literasi/article/view/2798/2462 
[15] P. Y. Kurniawan, and I. R. Amaliyah, "Analisis gejala linguistik dalam ranah perdagangan desa jatimakmur," Jurnal SEMANTIKA, vol. 1, no. 2, pp. 42-46, 2020, [Online]. Available: http://jurnal.umus.ac.id/index.php/semantika/article/view/170/106 